\title{
MRS Co-Sponsors Oxford Microscopy of Semiconductors Meeting
}

The Fourth Oxford Conference on Microscopy of Semiconducting Materials will be held March 25-27, 1985, at St. Catherine's College, Oxford, UK. Organized by the Royal Microscopical Society (UK), the meeting is co-sponsored by MRS and the Institute of Physics (UK). The conference chairmen are Dr. A. G. Cullis of the Royal Signals and Radar Establishment, Malvern, and Dr. D. B. Holt of Imperial College, London.

Dr. Cullis, long an active member of MRS, reports that the conference is expected to follow the successful pattern set in its three previous meetings. He explained that the

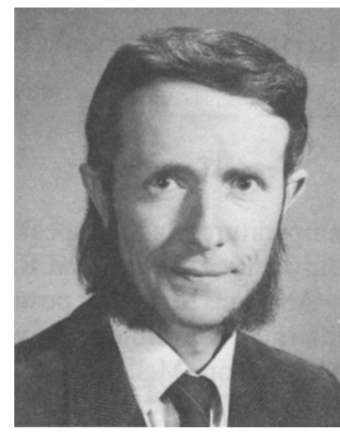

A. G. Cullis conference has become a central focus for semiconductor scientists in Europe and draws a sizable audience from North America as well. As in past years, the proceedings of the conference will be published as a volume in the Institute of Physics (UK) Proceedings Series.

\section{Conference Topics}

The primary focus of the Conference will be on recent advances in the understanding of the structural and electrical properties of semiconductors obtained by the use of electron microscopy. Both transmission and scanning microscopy studies of the complete range of elemental and compound semiconductors will be featured. Work using other analytical techniques such as x-ray topography, ion backscattering spectrometry, and nonconventional types of scanned image microscopy also will receive prominent coverage.

Special sessions will emphasize the latest development in a number of areas such as:

- properties of dislocations

- advances in high-resolution electron microscopy
- effects of transient processing methods

- semiconductor microanalysis

- electron beam testing of devices

\section{Keynote Speakers}

Among the major topics which invited speakers will introduce are those on the following provisional list:

- characterization of silicon-on-insulator (D. Bensahel, CNET)

- TEM of compound semiconductors (G. R. Booker, Oxford University)

- developments in STEM applications (L. M. Brown, Cambridge University)

- process-induced defects in silicon (C. L. Claeys, Catholic University of Leuven)

- electron beam testing of devices (S. M. Davidson, Lintech Instruments Ltd.)

- interfacial atomic structure (J. M. Gibson, AT\&T Bell Laboratories)

- dislocation networks in silicon and germanium (P. Haasen, Göttingen University)

- SEM EBIC and SDLTS studies (J. Heydenreich, DDR Academy of Sciences)

- silicide lateral diffusion couples ( J. W. Mayer, Cornell University)

- TEM of VLSI devices (H. Oppolzer, Siemens Research Laboratories)

- HREM defect studies (F. A. Ponce, Xerox Research Laboratories)

- $\mathrm{X}$-ray characterization of III-V materials (B. K. Tanner, Durham University)

\section{Registration}

For information on registration and housing accommodation (housing deadline is February 25), contact: Administrator, Royal Microscopical Society, 37/38 St. Clements, Oxford OX4 1AJ, England; telephone Oxford 248768 .

\section{Middleton Leaves MRS Bulletin Staff}

\section{Society recognizes contributions to editorial coverage during last three years}

Timothy Middleton, editor of the MRS BULLETIN since 1982, relinquished the post effective with the September/October issue. A part-time consultant to the Society, his need to devote more time to other matters coincided with the Society's desire to expand the BULLETIN under the direction of a fulltime editor. The appointment of Gail Oare as the Society's publications director was announced in the last issue of the BULLETIN.

Tim is a financial journalist in New York. In 1982 the Society's then President-Elect, Harry Leamy, AT\&T Bell Laboratories, wanted to revive the Society's moribund

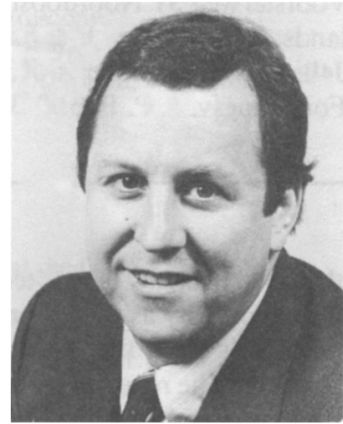

Tim Middleton newsletter, which had appeared infrequently as a four-page flyer without professional editorial help. He recruited Tim to help write articles about the Society's activities, and Tim gradually assumed more and more responsibility for the production of what was planned to be an eight-page bimonthly, newly named MRS BULLETIN.

The newsletter proved to be a vital link between a growing Society and its membership, and the BULLETIN began to grow in size and scope, publishing issues that expanded first to 12 , and later to as many as 36 pages, and included editorials, book reviews, and other features.

In the summer of 1984 , Tim was named an editor of a new business newspaper in New York, Crain's New York Business. It quickly became apparent to him he could not continue to edit the BULLETIN. Simultaneously, the Society was planning to expand it's editorial services, so a decision was made to hire a full-time professional.|

Tim, a graduate of Southern Illinois University, who lives in Short Hills, $\mathrm{NJ}$, had done a limited amount of writing on science and technical subjects when he began editing the BULLETIN.

"Obviously," he says, "I couldn't have written the kind of in-depth, professional-level articles we have published without alot of tutoring by people like Harry Leamy, Woody White, and Elton Kaufmann. The Society's leaders have consistently devoted tremendous resources to the BULLETIN particularly their own time. The materials profession owes them a great deal for the total commitment they have made to improving the dialogue among materials workers, and information available to them."

"I regret I haven't the time to continue to work with the Society, for I've made many friends among its members, and I greatly admire all of them," he says. "But the growth of the headquarters office indicates the Society has need now of professionals, like John Ballance and Gail Oare, to help its volunteer leadership provide an ever expanding and improving series of benefits to the membership." 